\title{
Entrepreneurial Motivations and Characteristics of Niger Delta Youths: An Exploratory Study
}

\author{
Anthony O. Aligba \\ International School of Management \\ Gene E. Fusch \\ Walden University
}

\begin{abstract}
This article explored the lived experiences and perceptions of youths in the Niger Delta regarding the factors that influence the decision to become an entrepreneur. Drawing from the theories of motivation and planned behavior, the conceptual framework of this phenomenological study underscored the synergetic relationship between entrepreneurial motivations and characteristics. Using semistructured interviews to collect primary data, 20 youth small and medium enterprise owners shared their perceptions and lived experiences regarding their perceived entrepreneurial motivations and characteristics. The analysis and coding of data helped to identify emergent themes based on the modified van Kaam sevenstep approach. The research findings revealed 19 dominant themes, including unemployment, the desire for control and freedom, financial independence, the willingness to take risks, determination, self-motivation, and persistence. This study may contribute to social change as more Niger Delta youths might become better enlightened to make a wellinformed decision about becoming an entrepreneur, which might potentially address the unemployment challenge in the region and enhance socioeconomic development.
\end{abstract}

Keywords: entrepreneurship, economic development, Niger Delta, unemployment, youth entrepreneurship

\section{Introduction}

In recent years, research on the Niger Delta has become pertinent in a bid to address the growing concerns about the socioeconomic and sociopolitical challenges confronting the region. The purpose of this article was to explore the lived experiences and perceptions of youths in the Niger Delta regarding the factors that influence the decision to become an entrepreneur. Although substantial research has been conducted on entrepreneurship development in Nigeria, the entrepreneurial motivations and characteristics of youths in the Niger Delta have not been sufficiently explored. Consequently, many youths continue searching for jobs because they lack knowledge of the factors necessary to become an entrepreneur.

The Niger Delta region, renowned for its rich mineral resources, in recent years became a subject of public discourse as scholars intensified research on topical issues associated with the region. The region is home to an estimated 30 million people (Okpara, 2012), representing approximately 20\% of the national population and deemed to have a growth rate of over $2.5 \%$ per annum (Satterthwaite, 2009). Within the past decade, the region became associated with youth restiveness, militancy, and various forms of social vices, which researchers have attributed mainly to the increasing 
unemployment rate among youths in the region (Oghojafor, Aduloju, \& Olowokudejo, 2011; Owualah \& Obokoh, 2008). When youths are jobless, they are likely to explore other avenues to meet their basic needs. Therefore, it has become crucial for Niger Delta youths to seek other legitimate sources of income for their livelihood.

The current study, thus, aims to complement previous research on entrepreneurship in Nigeria by exploring the entrepreneurial motivations and characteristics of Niger Delta youths. This study may contribute to social change as more youths in the Niger Delta become better enlightened about their entrepreneurial motivations and characteristics to enable them make well-informed decisions about choosing a career in entrepreneurship. An increased engagement in entrepreneurial undertakings may potentially address the unemployment challenge in the Niger Delta, enhance peaceful coexistence, and facilitate socioeconomic development.

\section{Background of the Study}

The youth population in Nigeria (18 to 35 years) constitutes approximately $60 \%$ of the national population (Oduwole, 2015). A significant portion of the youth population in Nigeria comprises graduates of postsecondary educational institutions (universities, polytechnics, and colleges of education). An estimated 120,000 youths complete postsecondary education annually (Oghojafor et al., 2011). Although some youths become gainfully employed or become entrepreneurs within a few years after postsecondary education (Brijlal, 2011), a greater percentage remain unemployed due to the scarcity of jobs (Ekore \& Okekeocha, 2012). The declining prospects for employment in the country pose immense challenges for Niger Delta youths as well as for the entire country as youths become constrained to explore other avenues to survive.

Entrepreneurship may effectively address the problem of unemployment (Owualah \& Obokoh, 2008). The prevailing unemployment challenge has made it imperative for unemployed youths to explore careers in entrepreneurship as a viable means to achieve their personal and financial goals. However, some youths may not be disposed to becoming self-employed, because they lack knowledge of the motivations and characteristics that may influence their decision to engage in entrepreneurial undertakings (Plattner, Lechaena, Mmolawa, \& Mzingwane, 2009). By examining Ajzen's (1985, 1991) theory of planned behavior (TPB) and McClelland's (1961) theory of motivation (acquired needs theory, ANT), the motivations and characteristics of 20 Niger Delta youth entrepreneurs were explored to understand the factors that influence the decision to seek a career in entrepreneurship. The central features of the TPB and ANT underscore the synergetic relationship between perceived entrepreneurial motivations and characteristics.

\section{Statement of the Problem}

The youth unemployment rate in sub-Saharan Africa was approximately $11.6 \%$ in 2014 (International Labour Organization, 2015), while the youth unemployment rate in Nigeria was approximately $13.6 \%$ in the same year (The World Bank, 2014). Only about $20 \%$ of new graduates from postsecondary educational institutions in Nigeria successfully obtain jobs after graduation annually (Adejimola \& Olufunmilayo, 2009; Snapps \& Hamilton, 2011). The low employment rate among graduates each year exacerbates the unemployment challenge in the country. However, some youths may not possess the entrepreneurial motivations and characteristics needed to become selfemployed (e.g., Plattner et al., 2009). The current study addresses the need to enlighten Niger Delta youths regarding their entrepreneurial motivations and characteristics that will enable them to make well-informed decisions about becoming entrepreneurs. 


\section{Conceptual Framework}

The conceptual framework for this study was based on two foundational theories, namely, the TPB and the theory of motivation, also called the ANT. The TPB establishes a correlation between attitudes and behaviors (Ajzen, 1985, 1991). A central feature of the TPB is the intention of an individual to carry out an activity. The ANT, on the other hand, stipulates that individuals acquire their specific needs over a given period as their personal experiences influence their needs (McClelland, 1961). The ANT focuses on three levels of motivation, namely, the need for achievement, the need for affiliation, and the need for power (Bijaoui, 2012). As Ajzen (1991) observed, a correlation exists between observable personal ideologies and the factors that influence an individual to engage in a certain behavior while motivating another individual to pursue a different area of interest. Essentially, the core features of the TPB and ANT provide insight into the entrepreneurial motivations and characteristics that influence individuals to choose a career in entrepreneurship.

\section{Literature Review}

For several decades, entrepreneurship has been a subject of intense debate among researchers and practitioners. The origin of the phenomenon is traceable to Richard Cantillon, the renowned economist, whose original contribution to the field of entrepreneurship may have given rise to many definitions (Ahmad \& Seymour, 2008). However, the definition proposed by Joseph Schumpeter formed the basis for many modern definitions, which have undergone various transformations through the years. Schumpeter (1934) described entrepreneurs as innovators who exploit change in diverse ways, and by extension exploit market opportunities. In the context of entrepreneurship, change implies an avenue for innovation and development (Betta, Jones, \& Latham, 2010). However, the main goal of entrepreneurship is to create value (Kobia \& Sikalieh, 2010). Creativity, therefore, is fundamental for enterprise development and sustainability.

\section{Entrepreneurship and Economic Development}

The role of entrepreneurship in economic development is common knowledge, and researchers across the globe have affirmed that entrepreneurship is a driver of economic growth and development (Ekore \& Okekeocha, 2012; Muharremi, Koprencka, \& Pelari, 2011). For several years, a key policy objective of governments has been to develop an economy that is inherently entrepreneurial (De Clercq, Menzies, Diochon, \& Gasse, 2009). The primary goal of entrepreneurship is to create new ventures (Drucker, 1985; Rangnekar, 2009), as the creation of new ventures is globally regarded as a means to create employment opportunities. In essence, entrepreneurship helps to tackle unemployment, leads to poverty reduction, and fosters economic growth (Tamvada, 2010).

In evaluating the importance of promoting entrepreneurship, small and medium enterprises (SMEs) come to the fore. SMEs are principal drivers of economic development, and constitute an integral part of the private sector. SMEs have immense potential for job creation and poverty reduction in developing economies (Hashi \& Krasniqi, 2011; Muharremi et al., 2011; Tamvada, 2010). For example, SMEs accounted for over $90 \%$ of the manufacturing sector in Nigeria in 2005, and over 3 million jobs in Kenya in 2003 (Sriram \& Mersha, 2010). These statistics, in addition to several others, affirm the significance of SMEs, and emphasize the need to promote the development of SMEs and the private sector to facilitate economic development. 


\section{Entrepreneurial Motivations and Characteristics}

The literature is replete with studies investigating the factors that influence the decision to create new ventures. Ajzen (1991) argued that intention largely determines the performance of a certain behavior, as it is an indication of the degree of willingness and effort of individuals to engage in a particular behavior. The intention to create a new venture originates primarily from personal motivation. Bijaoui (2012) posited that the absence of motivation impedes any plan for development. In essence, the lack of motivation to achieve more than is basic for survival robs an individual the impetus needed to accomplish greater goals. Bijaoui distinguished between three dimensions of motivation, namely, the need for achievement, the need for affiliation, and the need for power. These dimensions of motivation constitute various aspects of an individual's need, particularly in relation to creating the impetus for entrepreneurship.

Similarly, research has shown that entrepreneurial characteristics play a key role in the entrepreneurship decision process as well as in achieving business success. Barba-Sanchez and Atienza-Sahuquillo (2011) found that personal traits, abilities, and characteristics influence the decision to become self-employed. In the general, the main entrepreneurial characteristics described in the literature reveal several common themes, including risk-taking (Gelard \& Saleh, 2011; Jiao \& Robinson, 2011) and innovativeness or creativity (Leitao \& Franco, 2011; Kogut, Short, \& Wall, 2010). Other characteristics are optimism and self-confidence (Forgeard \& Seligman, 2012; Hayward, Forster, Sarasvathy, \& Fredrickson, 2010). Attributes such as passion, creativity, perseverance, and selflessness were also considered to be prerequisites for entrepreneurial success (Rozell, Meyer, Scroggins, \& Guo, 2011).

\section{Method}

The purpose of this qualitative phenomenological study was to explore the lived experiences and perceptions of youths in the Niger Delta regarding the entrepreneurial motivations and characteristics that influence the decision to become self-employed. Using a purposive sampling approach, the population selected for this study comprised 20 owners of SMEs. Per the selection criteria, all the research participants were graduates from various postsecondary institutions in Nigeria. Each of the participants was an owner or co-owner of a formal business. All participants lived and conducted business in the city of Port Harcourt-presumably the commercial hub of the Niger Delta. Table 1 summarizes the demographics of the research participants.

Semistructured and in-depth face-to-face interviews were conducted with each participant. The longest interview spanned approximately $45 \mathrm{~min}$. QSR NVivo software was used for data analysis, based on the modified van Kaam seven-step approach. Data analysis of participants' responses to the interview questions helped to address the central research question: What are the perceptions and lived experiences of Niger Delta youths regarding the entrepreneurial motivations and characteristics that influence the decision to become self-employed? 
Table 1. Sample Demographics of Participants

\begin{tabular}{lcc}
\hline Category & $n$ & \% of Participants \\
\hline Sex & 12 & 60 \\
Male & 8 & 40 \\
Female & & \\
Age & 0 & 0 \\
$\quad 18-24$ & 6 & 30 \\
$25-30$ & 14 & 70 \\
$31-40$ & 13 & 65 \\
Marital Status & 7 & 35 \\
$\quad$ Single & & \\
Married & &
\end{tabular}

Note. $N=20$.

\section{Results}

The data analysis of participants' responses revealed 19 core emergent themes, which included perceived entrepreneurial motivations and characteristics. Tables 2 and 3 summarize the core themes that emerged from the data analysis regarding the perceived entrepreneurial motivations and characteristics, respectively.

Table 2. Frequency of Emergent Themes: Entrepreneurial Motivations

\begin{tabular}{lcc} 
Motivation & $n$ & \% of Participants \\
\hline Unemployment or lack of desired jobs & 13 & 65 \\
Desire to make ends meet or earn a living & 9 & 45 \\
Financial independence & 9 & 45 \\
To help the less privileged or charity & 6 & 30 \\
Respect and social recognition & 4 & 20 \\
To secure retirement & 3 & 15 \\
Control and freedom or be own boss & 10 & 50 \\
To maximize talents and potentials & 5 & 25 \\
\hline
\end{tabular}

Note. $N=20$. 
Table 3. Frequency of Emergent Themes: Entrepreneurial Characteristics

\begin{tabular}{lcc} 
Characteristics & $n$ & \% of Participants \\
\hline Determination & 14 & 70 \\
Self-confidence & 6 & 30 \\
Passion & 6 & 30 \\
Integrity & 4 & 20 \\
Spirituality and faith & 7 & 35 \\
Vision & 11 & 55 \\
Optimism or a positive mindset & 8 & 40 \\
Self-motivation & 12 & 60 \\
Creativity & 7 & 35 \\
Willingness to take risks & 20 & 100 \\
Persistence & 8 & 40 \\
\hline
\end{tabular}

Note. $N=20$.

The following statements were a few of the responses from participants. To maintain confidentiality and protect the privacy of each participant, we used codes in place of participants' real names.

Extraneous data and redundant information were also not included in this presentation.

I think that the major reason our youths go into business is the lack of job opportunities... Basically, some people go into business because they have to earn a living; in the absence of jobs, they have to do something to survive. But to be self-employed, you must have a vision of what you really want to do. You have to be creative, willing to take risks, and determined to succeed. (XP1)

Niger Delta youths want to be able to fend for themselves and earn a living. Without a job, how else do you expect to feed and make ends meet? ...The only other way is to see how you can be useful to yourself by starting your business. It's a major step to take starting out on your own. But I believe that if you're determined, self-motivated and positive, you will make it. (XP6)

My motivation to become an entrepreneur was basically to work for myself and be financially independent. I was very passionate about starting my own business that I can be in absolute control of. Perhaps my family background had something to do with it too, because my parents were entrepreneurs. But I attribute my success in business to my faith in God, persistence, self-motivation, and determination to succeed... Niger Delta youths crave for financial independence. Also, they want to be respected and recognized in the society. Some people don't want to be bossed around. They prefer to be in control of things. Basically, being self-employed demands a sense of responsibility, determination, and self-motivation. Opportunities often present themselves, both good and bad, but you have to be willing to take some risks. (XP8)

My motivation to become an entrepreneur was born out of the passion I have to help the less privileged folks in the society. The Niger Delta is blessed with rich mineral resources, but the poverty and suffering among our people is too much. There are no jobs, yet one must survive. (XP12) 
One of the main factors that motivate youths to become self-employed is the lack of jobs...Secondly, many self-employed youths tend to make it faster than those that are working under somebody else; they seem to achieve financial independence quicker. In addition, those who are employed don't have job security and gratuity after they might have worked for years. But youths who are optimistic, creative, and prepared to take risk can achieve their goals. (XP15)

The truth is that everybody, including our youths, wants money...I think it's the desire to be financially independent that motivates us to become entrepreneurs, because the general belief is that it's the fastest way to be rich. It's not a smooth ride, though; of course, there are challenges along the way. As long as you've got vision, and you remain determined, confident, and optimistic enough to follow through, there is no challenge you cannot surmount. (XP20)

The research participants were also asked follow-up questions to support the central research question. Participants described their perceptions and views regarding the predisposition of Niger Delta youths toward risk-taking. The results indicated that although all participants affirmed that risk-taking is an important entrepreneurial characteristic (as indicated in Table 3), they expressed divergent views regarding the predisposition of Niger Delta youths toward risk-taking (see Table 4).

Table 4. Frequency Distribution of Participants' Views on the Risk-Taking Predisposition of Niger Delta Youths

\begin{tabular}{lcc}
\hline Code & $n$ & \% of Participants \\
\hline No & 6 & 30 \\
Undefined & 10 & 50 \\
Yes & 4 & 20 \\
\hline
\end{tabular}

Note. $N=20$.

A common theme uncovered from participants' responses was the significance of risk-taking. For example, Participant XP3 stated, "Life itself is a risk. If you are afraid of taking risk, you cannot make it." Participant XP17 posited, "Life is all about risk, and risks are inevitable." Similarly, Participant XP12 noted, "It is a normal phenomenon that business is about taking risk. Before you venture into a business, it is important to understand that risk is involved."

Participants' views were also solicited to gain better understanding of the general mindset of Niger Delta youths regarding their predisposition and willingness to become self-employed. As shown in Table 5, the findings revealed opposing views.

Table 5. Frequency Distribution of Participants' Views on the Entrepreneurial Predisposition of Niger Delta Youths

\begin{tabular}{lcc}
\hline Code & $n$ & \% of Participants \\
\hline No & 12 & 60 \\
Undefined & 1 & 5 \\
Yes & 7 & 35 \\
\hline
\end{tabular}

Note. $N=20$. 
According to Table 5, 60\% of the participants felt that youths in the Niger Delta were not inherently enterprising due to perceived indolence or an increased dependence on the mineral resources in the region, or a negative mindset; others asserted that the challenges confronting Niger Delta youths make them unable to explore entrepreneurial ventures. The following statement was a participant's response:

The truth is that our Niger Delta youths are primarily concerned about the "black gold" (crude oil). The Niger Delta produces the oil, and our youths feel they ought to be beneficiaries one way or the other instead of being marginalized. Basically, the agitation in the Niger Delta and the clamor for resource control might be having a negative impact on the mentality of some of our youths, in terms of self-development... (XP16)

\section{Discussion}

The research findings were consistent with the purpose and significance of the study. Drawing from the conceptual framework of this study, the results revealed compelling entrepreneurial motivations and characteristics of Niger Delta youths, underscoring the synergetic relationship between various factors that influence the decision to become an entrepreneur. The core themes that emerged played a significant role in helping to comprehend the research phenomenon as well as in addressing the central research question.

The frequency of occurrence of the dominant motivations varied significantly. As shown in Table 2, unemployment (or lack of desired jobs) represented $65 \%$ of the sample size. The reason for this high response rate, relative to the other motivations, may not be far-fetched. Oghojafor and colleagues (2011) found that an estimated 120,000 youths complete postsecondary education annually. Due to the scarcity of jobs, however, a greater percentage of youths remain unemployed (Ekore \& Okekeocha, 2012). Other dominant motivations resulting from the current study included the desire for control and freedom (50\%), financial independence (45\%), and the desire to make ends meet $(45 \%)$.

The frequency of participants' responses regarding a particular motivation may not necessarily indicate its degree of significance or strength of influence relative to other perceived motivations. However, the variation in the frequencies of occurrence implied that several motivational factors may influence a person's decision to become an entrepreneur. In essence, the motivations that influence one individual may not necessarily influence another, and the motivation(s) that one individual considers to have the strongest influence may not necessarily have any (or as much) influence on another individual.

As shown in Table 3, all the participants indicated that risk-taking was a core entrepreneurial characteristic that influenced their decision to become an entrepreneur, and these findings lend support to previous research. Jiao and Robinson (2011) noted that risk-taking is one of the essential elements that define people with a natural tendency to be entrepreneurs. Similarly, Gelard and Saleh (2010) argued that risk-taking and entrepreneurship are relatively interconnected. Other dominant entrepreneurial characteristics emerging from the current research were determination (70\%), self-motivation (60\%), vision (55\%), optimism (40\%), and persistence (40\%). 
The frequencies of occurrence of the core entrepreneurial characteristics varied from one participant to another (see Table 3). Although the frequency of participants' responses may not be indicative of the strength or degree of influence of a particular entrepreneurial characteristic, it is indicative of the comparative perceptions of the significance of each entrepreneurial characteristic to the respective participants. The variations in participants' responses may, however, suggest that several characteristics, as opposed to a single entrepreneurial characteristic, influence an individual's decision to become an entrepreneur.

Overall, the analysis of participants' responses revealed that the perceived entrepreneurial motivations and characteristics play a significant role in influencing the decision to become an entrepreneur. The research findings, thus, indicated that entrepreneurial motivations and characteristics are interdependent factors in the entrepreneurship decision-making process; hence, the knowledge of these factors may influence the decision of Niger Delta youths to engage in entrepreneurship. In addressing the central research question, therefore, the diversity of the entrepreneurial motivations and characteristics lends support to the argument that whereas the perceived experiences of individuals may influence their needs significantly (McClelland, 1961), various factors may influence one individual to take an action differently from another individual (Ajzen, 1991).

\section{Implications for Social Change}

This study might contribute to social change in several ways. First, the findings of this study might provide an enlightened view about the entrepreneurial motivations and characteristics of Niger Delta youths, equipping them with the knowledge needed to make informed decisions about choosing a career in entrepreneurship. As the theory of motivation stipulates, the intention to become an entrepreneur originates from perceived motivations (Bijaoui, 2012). An enlightened view about the entrepreneurial motivations and characteristics of Niger Delta youths might lead to increased entrepreneurial undertakings with the potential for a significant reduction in youth unemployment in the region.

Second, this study potentially creates a pathway to financial independence for Niger Delta youths. As the research findings revealed, the quest for financial independence and the desire to make ends meet are core motivations of Niger Delta youths. According to Omotola (2008), an estimated 70\% of families in Nigeria are indigent. In essence, increased entrepreneurial undertakings by Niger Delta youths might lead to financial independence, poverty-reduction, and facilitate socioeconomic development of the region. Furthermore, the findings of this study indicated that the engagement of youths in entrepreneurial endeavors might lead to a significant decline in the crime rate, youth restiveness, and other forms of social vices that have plagued the Niger Delta region for several years. Therefore, youth entrepreneurship might potentially address the insecurity situation in the Niger Delta, resulting in peaceful coexistence in the region.

\section{Recommendations}

This study serves as a medium to enlighten Niger Delta youths regarding their entrepreneurial motivations and characteristics to enable them make well-informed decisions about choosing a career in entrepreneurship. However, there is a need for stakeholders to introduce effective intervention schemes to enhance youth entrepreneurship development in the region. Latha and Murthy (2009) argued that governments owe small-scale businesses a responsibility to provide both financial and infrastructural support. The government, thus, plays a crucial role in helping to address some of the challenges confronting prospective and current entrepreneurs. 
Intervention schemes introduced by governments may be implemented through public-private partnerships aimed primarily, among other objectives, at establishing entrepreneurial training centers across the Niger Delta, and tackling the challenges associated with access to credit facilities by potential entrepreneurs. Moreover, this exploratory study serves as an additional source of information about important factors that influence the decision to choose a career in entrepreneurship. Consequently, the study constitutes a basis for further research into current and related topics pertaining to youth and entrepreneurship development in other regions of the country, as a potential strategy towards building a productive entrepreneurial ecosystem nationwide.

\section{Conclusion}

The main objective of this study was to explore the lived experiences and perceptions of Niger Delta youths regarding the factors that influence the decision to become an entrepreneur. The search for jobs is a major challenge that has not yielded significant results in terms of addressing the high unemployment rate and in curbing youth restiveness in the Niger Delta region. Despite the scarcity of job opportunities, many youths continue searching for jobs because they lack knowledge of the entrepreneurial motivations and characteristics necessary to become self-employed. The unemployment challenge and its attendant problems, raise serious concerns that elicit immediate attention from the government and relevant stakeholders.

The findings from the current study revealed core entrepreneurial motivations and characteristics that influence the decision to choose a career in entrepreneurship. By understanding the relevance of these factors, Niger Delta youths may be better positioned to make well-informed decisions that might help to address the high unemployment rate in the region. However, the potential for sustainable socioeconomic and regional development depends considerably on the responsiveness of government (at the local, state, and federal levels) towards instituting entrepreneur-friendly reforms necessary to facilitate the creation and growth of SMEs in the region. With the national youth unemployment rate reaching $42.24 \%$ in the first quarter of 2016 , according to the National Bureau of Statistics (2016), the renewed call for youths' engagement in entrepreneurship was never more urgent and crucial.

\section{References}

Adejimola, A. S., \& Olufunmilayo, T. (2009). Spinning off an entrepreneurship culture among Nigerian university students: Prospects and challenges. African Journal of Business Management, 3, 80-88.

Ahmad, N., \& Seymour, R. G. (2008). Defining entrepreneurial activity: Definitions supporting frameworks for data collection (Working paper). Paris, France: OECD Statistics. Retrieved from http://www.oecd.org/officialdocuments/publicdisplaydocumentpdf/?doclanguage=en\&cote=std/ $\operatorname{doc}(2008) 1$

Ajzen, I. (1985). From intentions to actions: A theory of planned behavior. In J. Kuhl \& J. Beckmann (Eds.), Action control: From cognition to behavior (pp. 11-39). Heidelberg, Germany: Springer.

Ajzen, I. (1991). The theory of planned behavior. Organizational Behavior and Human Decision Processes, 50, 179-211. 
Barba-Sanchez, V., \& Atienza-Sahuquillo, C. (2011). Reasons to create a new venture: A determinant of entrepreneurial profiles. African Journal of Business Management, 5, 11497-11504. doi:10.5897/AJBM11.1131

Betta, M., Jones, R., \& Latham, J. (2010). Entrepreneurship and the innovative self: A Schumpeterian reflection. International Journal of Entrepreneurial Behaviour \& Research, 16, 229-244. doi:10.1108/13552551011042807

Bijaoui, I. (2012). From necessity to business entrepreneurship: The case of the Songhai center, Porto Novo, Benin. African Journal of Business Management, 6, 5872-5878. doi:10.5897/AJBM12.302

Brijlal, P. (2011). Entrepreneurial perceptions and knowledge: A survey of final year university students. African Journal of Business Management, 5, 818-825.

De Clercq, D., Menzies, T. V., Diochon, M., \& Gasse, Y. (2009). Explaining nascent entrepreneurs' goal commitment: An exploratory study. Journal of Small Business and Entrepreneurship, $22,123-139$.

Drucker, P. F. (1985). Innovation and entrepreneurship: Practice and principles. New York, NY: Harper Business.

Ekore, J. O., \& Okekeocha, O. C. (2012). Fear of entrepreneurship among university graduates: A psychological analysis. International Journal of Management, 29, 515-524. Retrieved from www.internationaljournalofmanagement.co.uk

Forgeard, M. J., \& Seligman, M. E. (2012). Seeing the glass half full: A review of the causes and consequences of optimism. Pratiques Psychologiques, 18, 107-120. doi:10.1016/j.prps.2012.02.002

Gelard, P., \& Saleh, K. E. (2011). Impact of some contextual factors on entrepreneurial intention of university students. African Journal of Business Management, 5, 10707-10717.

Hashi, I., \& Krasniqi, B. A. (2011). Entrepreneurship and SME growth: Evidence from advanced and laggard transition economies. International Journal of Entrepreneurial Behaviour \& Research, 17, 456-487. doi:10.1108/13552551111158817

Hayward, M. L., Forster, W. R., Sarasvathy, S. D., \& Fredrickson, B. L. (2010). Beyond hubris: How highly confident entrepreneurs rebound to venture again. Journal of Business Venturing, 25, 569-578. doi:10.1016/j.jbusvent.2009.03.002

International Labour Organization. (2015). Global employment trends for youth 2015. Retrieved from http://www.ilo.org/wcmsp5/groups/public/---dgreports/---dcomm/--publ/documents/publication/wcms_412015.pdf

Jiao, H., \& Robinson, J. A. (2011). Building international entrepreneurship through entrepreneurship capital perspective. African Journal of Business Management, 5, 84588469.

Kobia, M., \& Sikalieh, D. (2010). Towards a search for the meaning of entrepreneurship. Journal of European Industrial Training, 34, 110-127. doi:10.1108/03090591011023970

Kogut, C. A., Short, L. E., \& Wall, J. L. (2010). Entrepreneurship: The basis for Central European economic development. International Journal of Entrepreneurship, 14, 13-23.

Latha, L. K., \& Murthy, B. E. (2009). The motives of small scale entrepreneurs: An exploratory study. South Asian Journal of Management, 16, 91-108. 
Leitao, J., \& Franco, M. (2011). Individual entrepreneurship capacity and small and medium enterprises (SME) performance: A human and organizational capital approach. African Journal of Business Management, 5, 6350-6365.

McClelland, D. C. (1961). The achieving society. Princeton, NJ: D. Van Nostrand.

Muharremi, O., Koprencka, L., \& Pelari, E. (2011). SMEs: Their progress in the Albanian economy. Economics, Management, and Financial Markets, 6, 699-712.

National Bureau of Statistics. (2016). Unemployment/underemployment watch Q1 2016. Retrieved from http://www.nigerianstat.gov.ng/download/397

Oduwole, T. A. (2015). Youth unemployment and poverty in Nigeria. International Journal of Sociology and Anthropology Research, 1, 23-39.

Oghojafor, B. E., Aduloju, S. A., \& Olowokudejo, F. F. (2011). Social entrepreneurship as an instrument for curbing youth gangsterism: A study of the Nigerian urban communities. Journal of Economics and International Finance, 3, 616-623.

Okpara, C. I. (2012). Right to a clean and healthy environment: The panacea to the Niger Delta struggle. Journal of Politics and Law, 5, 3-8. Retrieved from http://www.ccsenet.org/jpl

Omotola, J. S. (2008). Combating poverty for sustainable human development in Nigeria: The continuing struggle. Journal of Poverty, 12, 496-517. doi:10.1080/10875540802352621

Owualah, S. I., \& Obokoh, L. O. (2008). Tackling youth restiveness in the Niger Delta region of Nigeria through entrepreneurship. Journal of Enterprising Communities: People and Places in the Global Economy, 2, 168-179. doi:10.1108/17506200810879989

Plattner, I. E., Lechaena, M., Mmolawa, W., \& Mzingwane, B. (2009). Are university students psychologically ready for entrepreneurship? A Botswana study. African Journal of Business Management, 3, 305-310.

Rangnekar, S. S. (2009). Entrepreneurship: Yesterday, today, and tomorrow. SIES Journal of Management, 6, 23-25.

Rozell, E. J., Meyer, K. E., Scroggins, W. A., \& Guo, A. (2011). Perceptions of the characteristics of successful entrepreneurs: An empirical study in China. International Journal of Management, 28, 60-71.

Satterthwaite, D. (2009). The implications of population growth and urbanization for climate change. Environment and Urbanization, 21, 545-567. doi:10.1177/0956247809344361

Schumpeter, J. A. (1934). The theory of economic development: An inquiry into profits, capital, credit, interest, and the business cycle. Cambridge, MA: Harvard University Press.

Snapps, O. J., \& Hamilton, D. I. (2011). Youth restiveness and industrial disruption in the Niger Delta. American Review of Political Economy, 9, 18-32.

Sriram, V., \& Mersha, T. (2010). Stimulating entrepreneurship in Africa. World Journal of Enterprenuership, Management and Sustainable Development, 6, 257-272.

Tamvada, J. P. (2010). Entrepreneurship and welfare. Small Business Economics, 34, 65-79. doi:10.1007/s11187-009-9195-5

The World Bank. (2014). Unemployment, youth total (\% of total labor force ages 15-24) (modeled ILO estimate) [Data file]. Retrieved from http://data.worldbank.org/indicator/SL.UEM.1524.ZS 
The Journal of Social Change, sponsored by Walden University, welcomes manuscripts focusing on interdisciplinary research in social change that improves the human condition and moves people, groups, organizations, cultures, and society toward a more positive future.

Walden University Publishing: http://www.publishing.waldenu.edu 